\title{
Sex difference in thermal preference of adult mice does not depend on presence of the gonads
}

\author{
Kasiphak Kaikaew ${ }^{1,2}$, Jacobie Steenbergen ${ }^{1}$, Axel P. N. Themmen', Jenny A. Visser ${ }^{1}$ and Aldo Grefhorst ${ }^{1 *}$
}

\begin{abstract}
Background: The thermoneutral zone (TNZ) is a species-specific range of ambient temperature $\left(T_{\mathrm{a}}\right)$, at which mammals can maintain a constant body temperature with the lowest metabolic rate. The TNZ for an adult mouse is between 26 and $34{ }^{\circ} \mathrm{C}$. Interestingly, female mice prefer a higher $T_{\text {a }}$ than male mice although the underlying mechanism for this sex difference is unknown. Here, we tested whether gonadal hormones are dominant factors controlling temperature preference in male and female mice.
\end{abstract}

Methods: We performed a temperature preference test in which 10-week-old gonadectomized and sham-operated male and female $\mathrm{C} 57 \mathrm{BL} / 6 \mathrm{~J}$ mice were allowed to choose to reside at the thermoneutral cage of $29^{\circ} \mathrm{C}$ or an experimental cage of 26,29 , or $32^{\circ} \mathrm{C}$.

Results: All mice preferred a $T_{a}$ higher than $26^{\circ} \mathrm{C}$, especially in the inactive phase. Choosing between 29 and $32{ }^{\circ} \mathrm{C}$, female mice resided more at $32{ }^{\circ} \mathrm{C}$ while male mice had no preference between the temperatures. Hence, the preferred $T_{\mathrm{a}}$ for female mice was significantly higher $\left(0.9 \pm 0.2^{\circ} \mathrm{C}\right)$ than that for male mice. However, gonadectomy did not influence the $T_{\text {a }}$ preference.

Conclusions: Female mice prefer a warmer environment than male mice, a difference not affected by gonadectomy. This suggests that thermal-sensing mechanisms may be influenced by sex-specific pathways other than gonadal factors or that the thermoregulatory set point has already been determined prior to puberty.

Keywords: Sex, Gonadectomy, Estrogen, Progesterone, Testosterone, Thermosensing, Body temperature regulation, Thermogenesis, Nesting behavior, Dark-light cycle

\section{Background}

Mammals prefer ranges of ambient temperature $\left(T_{\mathrm{a}}\right)$ within their species-specific thermoneutral zone (TNZ) at which their metabolic rate is at its lowest and theoretically equal to their basal metabolic rate. To control the core body temperature $\left(T_{\mathrm{c}}\right)$ in TNZ, only dry heat loss, i.e., skin blood flow, is sufficient. However, metabolic heat production or evaporative heat loss is required to regulate $T_{\mathrm{c}}$ at a $T_{\mathrm{a}}$ outside the TNZ [1]. Disturbances in $T_{\mathrm{a}}$ can alter normal physiological responses such as dietary requirement, cardiovascular functions, and reproduction capacity $[2,3]$; thus, it is important to be

\footnotetext{
* Correspondence: a.grefhorst@erasmusmc.nl

${ }^{1}$ Department of Internal Medicine, Erasmus MC, University Medical Center

Rotterdam, PO Box 2040, 3000 CA Rotterdam, The Netherlands

Full list of author information is available at the end of the article
}

aware of the changes of $T_{\mathrm{a}}$. The TNZ for an adult mouse is considered to be broad and in between 26 and $34{ }^{\circ} \mathrm{C}$, and mice therefore prefer a $T_{\mathrm{a}}$ between 29 and $31^{\circ} \mathrm{C}$ [4]. However, general animal facilities apply a $T_{\mathrm{a}}$ for laboratory mice in the range of $20-24{ }^{\circ} \mathrm{C}$ [5], which matches a thermal comfort of husbandry staffs and handling procedures but poses a persistent moderate cold stress to mice [6] affecting their physiological processes [7].

Many factors contribute to distinct patterns of thermal preference among mice. For instance, since mice are nocturnal animals, their motor activity has a diurnal rhythm which peaks in the dark phase. An increase in heat production related to this physical activity during the active phase results in a preference for a lower $T_{\mathrm{a}}$ to maintain $T_{\mathrm{c}}$ at night [6]. In addition, a higher $T_{\mathrm{a}}$ is required by neonatal mice due to limitations in their 
thermal regulatory mechanisms [8]. Elderly mice also require higher $T_{\mathrm{a}}$ due to changes in total body surface area (BSA). Upon growth, the BSA to body mass ratio decreases resulting in less capacity to exchange heat with the environment [4, 9]. Finally, thermal differences in mice have a sex-dependent pattern: female mice prefer a slightly higher $T_{\mathrm{a}}$ than male mice of the same age, especially in the inactive phase [10].

The mechanism(s) that underlie the differences in thermal regulation and preference between sexes are not clearly understood, but gonadal hormones such as the female sex hormones estradiol and progesterone and the male sex hormone testosterone might be considered dominant factors. The overall $T_{\mathrm{c}}$ of post-pubertal female mice is $0.2-0.5{ }^{\circ} \mathrm{C}$ higher than that of male mice, especially when the levels of progesterone and, to a lesser extent, estradiol are elevated during the estrous cycle [11]. Of interest, this higher $T_{\mathrm{c}}$ in female mice is not due to the difference in locomotor activity between male and female mice [11]. Progesterone shifts the thermoregulatory set point in the central nervous system resulting in an increase of basal $T_{\mathrm{c}}$ in the luteal phase of the human ovarian cycle [12]. Since the mouse estrous cycle lasts only $4-5$ days and does not include a true luteal phase, major and prolonged elevations of progesterone are only seen during (pseudo)pregnancy [13]. Estradiol influences energy balance by increasing the energy expenditure through modulation of central neuronal circuits [14], which includes the production of heat by brown adipose tissue (BAT) [15]. BAT is an important source of heat production in rodents, especially in the inactive phase. Interestingly, both estradiol and progesterone also directly stimulate biogenesis of brown adipocytes while testosterone inhibits differentiation of brown adipocytes $[16,17]$. However, the effects of gonadal hormones on the thermal preferences in mammals are not clearly studied.

To elucidate the effects of gonadal hormones on thermal preference, we performed temperature preference tests (TPTs) in adult mice of both sexes, in a range of $T_{\mathrm{a}}$ close to their TNZ. The results of the TPTs will reveal whether removal of gonadal hormones by gonadectomy (GDX) affects temperature preference.

\section{Methods}

\section{Animals and housing conditions}

Six-week-old C57BL/6J mice (16 male and 16 female mice) were obtained from Charles River Laboratories (Maastricht, the Netherlands). Upon arrival, the mice were housed for 1 week in groups of three animals in standard laboratory cages (Sealsafe 1145T, Tecniplast, Buguggiate, Italy; $36.9 \mathrm{~cm} L \times 15.6 \mathrm{~cm} W \times 13.2 \mathrm{~cm} \mathrm{H}$ ) with bedding material (Lignocel BK 8/15, J. Rettenmaier \& Söhne $\mathrm{GmbH}$, Rosenberg, Germany) and nesting material (facial tissue paper, Tork, SCA Hygiene Products, Zeist, the Netherlands) on a 12:12-h light-dark cycle (lights on at 8 a.m.), at temperatures of $21-23{ }^{\circ} \mathrm{C}$ with 40-70\% relative humidity. Chow food pellets (801727 CRM (P), Special Diets Services, Essex, UK) and water were available ad libitum. After the 1-week acclimatization, the mice were housed individually in a cage of the same setting for 3 days before the first series of TPTs was started. Thus, the mice were about 8 weeks old when enrolled in the experimental setups. All experimental procedures were performed with the approval of the Animal Ethics Committee at Erasmus MC, Rotterdam, the Netherlands.

\section{Temperature preference test setup}

For the TPT, a setup was designed based on the thermal preference apparatus by Gaskill BN et al. [18]. To connect two cages, an opening was drilled in one wall of each cage $(4 \mathrm{~cm}$ diameter at the position of $7.5 \mathrm{~cm}$ from the cage floor) and a black corrugated connecting tube was placed, as shown in Fig. 1a, b. Water baths, in which electric submersible aquarium heaters and water pumps (Superfish Combi Heater and Aqua-Flow, Aquadistri, Cambridgeshire, UK) were installed, were used to maintain a constant $T_{\mathrm{a}}$ in the cages. The water bath was filled with water to the level of $7.5 \mathrm{~cm}$ depth, and the cages were fastened by fabric straps to ensure that the water level was $5 \mathrm{~cm}$ from the cage bottom. At this water level, the $T_{\mathrm{a}}$ inside the cage (measured at the floor) was less than $0.5{ }^{\circ} \mathrm{C}$ different from the temperature in the water bath. Each cage contained a bottle of water, food pellets, nesting material (one sheet of the facial tissue paper, two layers per sheet, size $20 \mathrm{~cm} \times 21 \mathrm{~cm}$, weight $1.3 \mathrm{~g}$ ), and bedding material $(0.5 \mathrm{~cm}$ depth of Lignocel BK 8/15 woodchips). The mice were allowed to freely explore both cages. To prevent position bias from adjacent cages, opaque plastic sheets were placed as visual barriers between the cages. In total, the setup consisted of six TPT sets (Fig. 1b) for studying six mice simultaneously.

\section{Experimental design}

The total experimental procedure had a duration of 6 weeks, consisting of weeks 1 and 2 for adaptation to the TPT setup, week 3 for surgical procedure and recovery, and weeks 4 to 6 for behavioral observation (Fig. 1c). In the adaptation period (weeks 1 and 2) and the experimental period (weeks 4, 5, and 6), we performed the TPT in a total of $96 \mathrm{~h}$ after which the mice returned to their individual cages for the weekends. On Mondays, the temperature of the outer cages (the experimental cages) was set at $23{ }^{\circ} \mathrm{C}$ to mimic the general animal facility environment, while the temperature of the middle cages (the thermoneutral (TMN) cages) was set at $29^{\circ} \mathrm{C}$. 


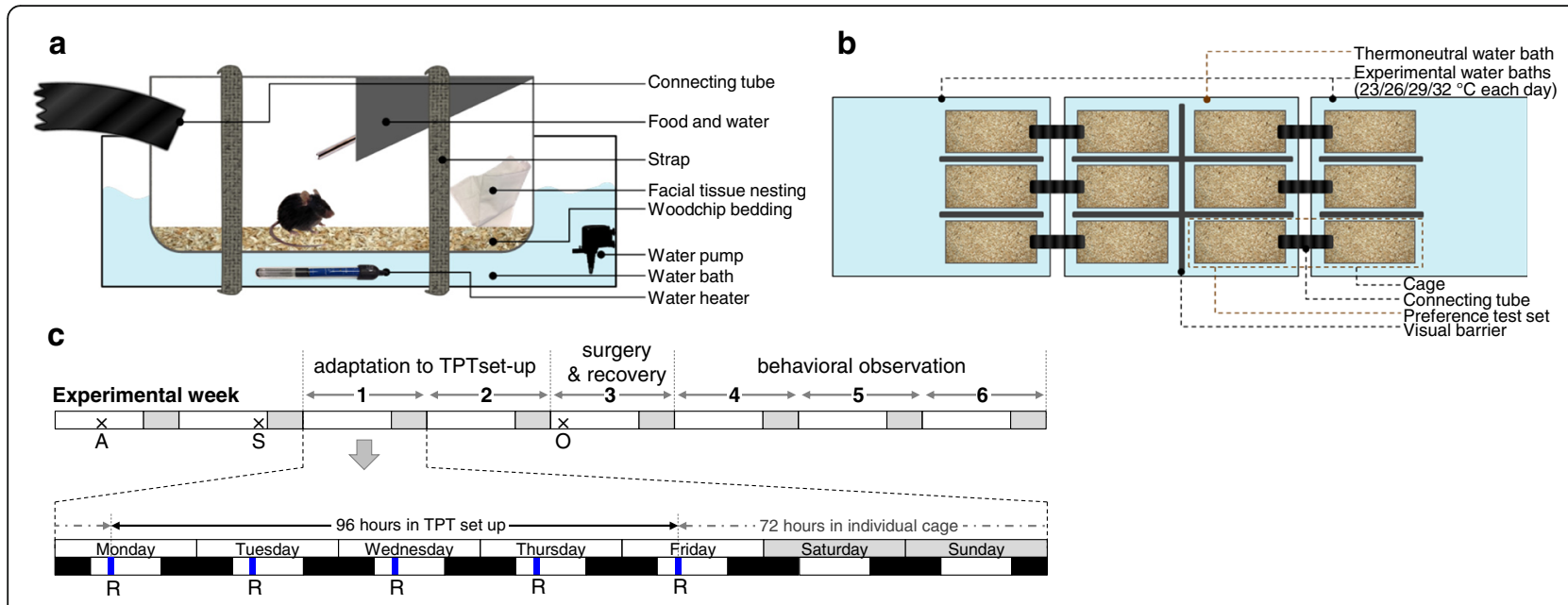

Fig. 1 Experimental design. a Side view of each experimental cage showing cage enrichments provided for each mouse. $\mathbf{b}$ Top view of six temperature preference sets of which the two outer water baths were set at a different experimental temperature each day, while the middle water bath was kept constant at $29^{\circ} \mathrm{C}$. c Experimental scheme. Abbreviations: $A$ arrival of mice, $\mathrm{S}$ separation to individual cage, $\mathrm{O}$ surgical operation, $R$ daily routine care

The routine care was performed daily between 1 and 2 p.m. including replacing of bedding and nesting material, weighing mice and food, and adjusting the temperature of the experimental cages to 26,29 , and $32{ }^{\circ} \mathrm{C}$ on Tuesday, Wednesday, and Thursday, respectively. The temperature of the TMN cages was kept at $29{ }^{\circ} \mathrm{C}$ throughout the week. After the daily routine, the mouse was put back in its experimental cage. The cages and water baths were cleaned thoroughly at the end of every week. For the surgical week (experimental week 3), the mice were randomized to undergo GDX or sham operation on Monday. After the surgery, the mice were allowed to recover for 7 days in their individual cages. To reduce the effect of position bias, the mice were relocated to an adjacent TPT set in the following week.

\section{Gonadectomy}

GDX was operated under isoflurane (Isofluraan, Teva Pharmachemie, Haarlem, the Netherlands) anesthesia and carprofen (Rimadyl Cattle, Pfizer, Capelle a/d IJssel, the Netherlands) analgesia. For the GDX of female mice, small incisions were made in both flanks to remove the ovaries. In the male mice, small incisions were made in the lower abdomen through which the testes were removed. Sham-operated animals underwent the same procedures without removal of ovaries or testes. Bleeding was verified and stopped and then the muscle layer and skin were sutured.

\section{Termination of mice}

In the week after the last TPT, the mice were euthanized by cardiac puncture under isoflurane anesthesia. For the female mice, the uterus was dissected and weighed to verify if the ovariectomy was successful.

\section{Behavioral observation, data collection, and analysis}

The thermal preference of each mouse was recorded by webcams (Exis, Trust, Dordrecht, the Netherlands) with the time-lapse function of Netcam Studio software (Moonware Studios) resulting in pictures with a 5-min interval that were collected for $23 \mathrm{~h}$, excluding the hour of the daily routine period. In the dark period, the photographs were taken under red lights. After a pilot study (results not shown), the periods of 9-12 p.m. and 912 a.m. (starting $1 \mathrm{~h}$ after light off and on, respectively) were selected for the study. Data from the mice that failed to explore both the experimental and the TMN cage for the whole experimental period were excluded from data analysis.

After weighing the mice and the food in all the cages during the routine care, the bedding and nesting materials were gathered for further processing. Feces were sorted out from the woodchip bedding and weighed. The nesting material was unfolded, put on a black board, and photographed for analysis by three assessors. The "paperwork score," modified from Kalueff et al. [19], was assessed to quantify how active a mouse was in biting and shredding the paper. This score ranges from 1 to 4 : 1 -without or little paper damage $(<5 \%$ of destruction compared to the total area of the nest), 2-mild paper damage (5-25\%), 3-moderate paper damage (25-50\%), and 4 -severe paper damage ( $>50 \%)$, as shown in Additional file 1: Figure S1. An average overall agreement of the paperwork score by three blinded assessors equaled to $84.7 \%(\kappa=0.79)$, without any more-than-1 ordinal 
score discrepancy. Since the nesting material can be transferred from one cage to the other, we also assessed the "nest score" for each cage. This score is calculated as follows:

Nest score $=(($ paperwork score $) / 4) \times($ relative amount of nest in the cage).

In this, the relative amount of nest is a proportion of nest weight in that cage to the total weight of the nesting material provided to the animal, ranging from 0 to 1 . For comparison between the experimental and the TMN cage of each mouse, the higher paperwork score and the higher nest score were used for data analysis.

The BSA of the mice was calculated by Meeh's formula with the C57BL/6J specific constant as described by Cheung et al. [20]:

$$
\mathrm{BSA}=9.822 \times \mathrm{BW}^{0.667} .
$$

In this, BW is the body weight in gram and BSA is the surface in square centimeter $\left(\mathrm{cm}^{2}\right)$.

Baseline characteristics of mice taken during the adaptation weeks are provided in Additional file 1: Table S1.

\section{Statistical analysis}

The statistical tests were performed using IBM SPSS Statistics for Windows, version 21 (IBM Corp.) with $p<.05$ considered statistically significant. Unless otherwise stated, the effects of experimental $T_{\mathrm{a}}$, sex of mice, and gonadal status were analyzed by repeated three-way ANOVA, and then, the post hoc tests were evaluated by two-way ANOVA for the effects of sex and gonadal status in each $T_{\mathrm{a}}$ and Tukey tests to determine differences among groups. The $p$ values of $T_{\mathrm{a}}$, sex, and gonadal status are indicated by $p_{\mathrm{T}}, p_{\mathrm{S}}$, and $p_{\mathrm{G}}$, respectively. The proportion of time that a mouse spent in each cage was arcsine transformed. The preference to either the TMN cage or the experimental cage in each $T_{\mathrm{a}}$ was analyzed by one-sample $t$ test. Correlations between the time-weighted average $T_{\mathrm{a}}$ and other factors were calculated by Pearson's correlation coefficient. All data are presented as mean \pm SD unless otherwise indicated.

\section{Results}

Gonadectomy affected the energy balance pattern mainly in female mice

GDX differentially affected body weight (BW) in male and female mice. While ovariectomy increased $\mathrm{BW}$ of female mice, orchiectomy did not affect BW of male mice during the study period. As a result, the BW of gonadectomized female mice was higher than the shamoperated female mice in the last experimental week (two-way ANOVA: $p_{\mathrm{S}}<.001, p_{\mathrm{G}}=.011, p_{\mathrm{S} \times \mathrm{G}}=.014$; Fig. 2a). In addition, the ratio of BSA to BW at the start of the last experimental week depended significantly on both sex and gonadal status (female sham $3.57 \pm$ $0.03 \mathrm{~cm}^{2} / \mathrm{g}$, female GDX $3.43 \pm 0.09 \mathrm{~cm}^{2} / \mathrm{g}$, male sham $3.32 \pm 0.04 \mathrm{~cm}^{2} / \mathrm{g}$, and male GDX $3.33 \pm 0.07 \mathrm{~cm}^{2} / \mathrm{g}$; two-way ANOVA: $p_{\mathrm{S}}<.001, p_{\mathrm{G}}=.013, p_{\mathrm{S} \times \mathrm{G}}=.006$; Tukey post hoc test revealed $p<.05$ for all pairs except sham-operated male vs gonadectomized male mice).

In general, the experimental $T_{\mathrm{a}}$ influenced the relative daily food intake $\left(p_{\mathrm{T}}=.003\right)$ and female mice ate relatively more than male mice without an effect of gonadal status $\left(p_{\mathrm{S}}<.001\right.$; Fig. $\left.2 \mathrm{~b}\right)$. However, the negative correlation of $T_{\mathrm{a}}$ on daily food intake was only significant for sham-operated male mice $(r=-.54, p=.011)$. In line with the food intake, the experimental $T_{\mathrm{a}}$ was related to the relative fecal production $\left(p_{\mathrm{T}}=.018\right)$. Moreover, the fecal production of female mice was higher than that of male mice, with a significant interaction between sex and gonadal status $\left(p_{\mathrm{S}}<.001, p_{\mathrm{S} \times \mathrm{G}}=.049\right.$; Fig. $\left.2 \mathrm{c}\right)$. Although the general trend of daily food intake (energy input) was negatively correlated with the experimental $T_{\mathrm{a}}$, the daily BW change of mice tended to positively correlate with the experimental $T_{\mathrm{a}}$ without a significant effect of sex or gonadal status but with a significant interaction between $T_{\mathrm{a}}$, sex, and gonadal status $\left(p_{\mathrm{T}}=.002, p_{\mathrm{T} \times \mathrm{S} \times \mathrm{G}}\right.$ $=.002$; Fig. $2 \mathrm{~d}$ ). The positive correlations between $T_{\mathrm{a}}$ and daily BW change were significant in sham-operated female mice $(r=.62, p=.003)$ and gonadectomized male mice $(r=.54, p=.007)$.

\section{Female mice preferred a higher ambient temperature, especially in the inactive phase}

The time mice spent in the TMN cage was influenced by experimental $T_{\mathrm{a}}$, sex, and the interaction between these factors, but was not altered by gonadal status $\left(p_{\mathrm{T}}<.001\right.$, $p_{\mathrm{S}}<.001, p_{\mathrm{T} \times \mathrm{S}}=.002, p_{\mathrm{T} \times \mathrm{S} \times \mathrm{G}}=.004$; Fig. 3a). When the $T_{\mathrm{a}}$ of the experimental cages was set at $26{ }^{\circ} \mathrm{C}$, all groups of mice preferred to reside in the TMN cages rather than the experimental cages $\left(p_{\mathrm{S}}=.038, p_{\mathrm{S} \times \mathrm{G}}=.026\right.$; Fig. 3a). Calculated from the cage preference data, the timeweighted average $T_{\mathrm{a}}$ the mice were exposed to was slightly higher for male than for female mice, with a significant interaction between sex and gonadal status (female sham $28.3 \pm 0.3{ }^{\circ} \mathrm{C}$, female GDX $28.1 \pm 0.2{ }^{\circ} \mathrm{C}$, male sham $28.3 \pm 0.3{ }^{\circ} \mathrm{C}$, male GDX $28.5 \pm 0.3{ }^{\circ} \mathrm{C} ; p_{\mathrm{S}}=.044$, $p_{\mathrm{S} \times \mathrm{G}}=.030$; Fig. $\left.3 \mathrm{~b}\right)$. When the $T_{\mathrm{a}}$ of the experimental cages was set the same as of the TMN cages at $29{ }^{\circ} \mathrm{C}$, male mice (both sham-operated and gonadectomized) resided more in the TMN cages while female mice had no preference to either cage $\left(p_{\mathrm{S}}<.001, p_{\mathrm{S} \times \mathrm{G}}=.033\right.$; Fig. 3a). When the $T_{\mathrm{a}}$ of the experimental cages was set at $32{ }^{\circ} \mathrm{C}$, female mice (both sham-operated and gonadectomized) spent more time in the experimental cage than in the TMN cage, while sham-operated male mice preferred the TMN cage and gonadectomized male mice had no preference for either the TMN or the $32{ }^{\circ} \mathrm{C}$ cage 
a

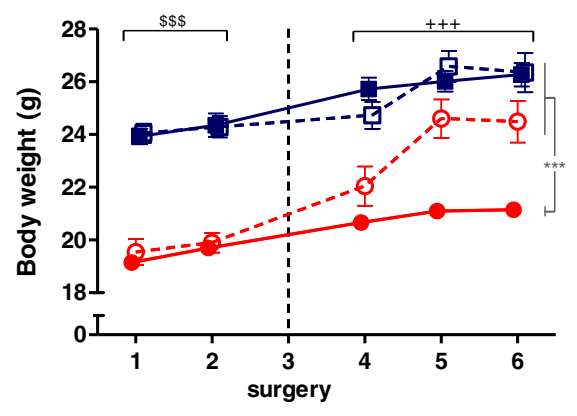

Experimental week

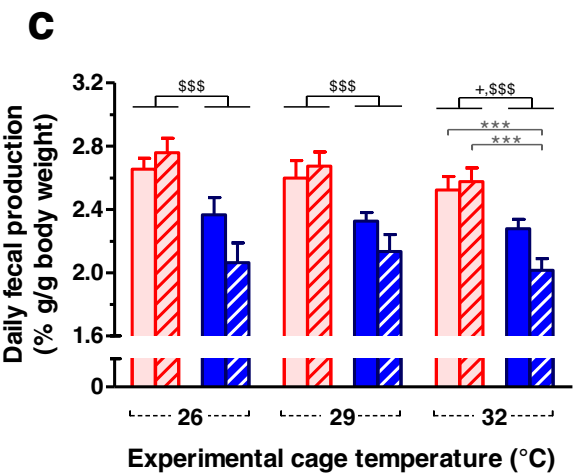

b

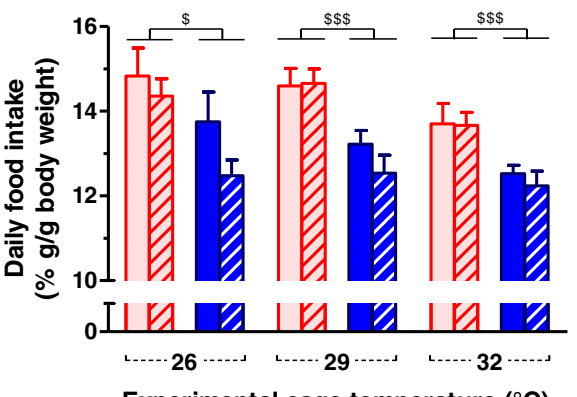

Experimental cage temperature $\left({ }^{\circ} \mathrm{C}\right)$

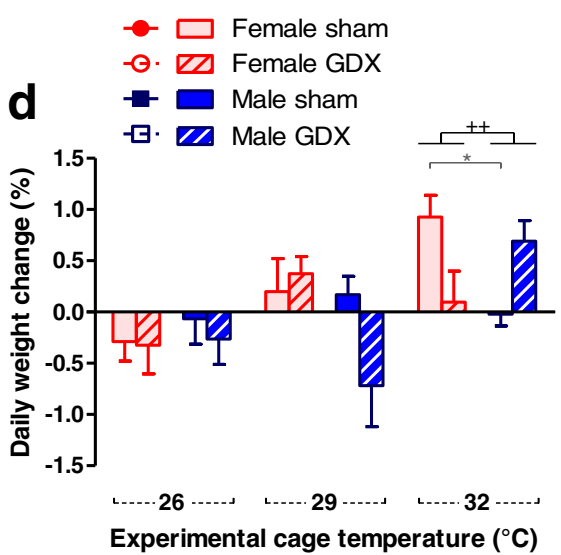

Fig. 2 Gonadectomy affected the energy balance pattern mainly in female mice. a Gonadectomy increased body weight only in female mice. Weights of mice measured at the first day of each experimental week are plotted. $\mathbf{b}$ Daily food intake and $\mathbf{c}$ fecal production were higher in female mice with negative correlations with the experimental $T_{\mathrm{a}}$. $\mathbf{d}$ Body weight was unchanged during the 24-h period in the experimental setup when the experimental $T_{a}$ was set at 26 and $29^{\circ} \mathrm{C}$, but some groups of mice gained weight when the experimental $T_{a}$ was set at $32{ }^{\circ} \mathrm{C}$. Two-way ANOVA: ${ }^{\$} p_{S}<.05,{ }^{\$ \$ \$} p_{S}<.001,{ }^{+} p_{S \times G}<.05,{ }^{++} p_{S \times G}<.01,{ }^{+++} p_{S \times G}<.001$, and Tukey test: ${ }^{*} p<0.05,{ }^{* * *} p<0.001$. Error bar indicates SEM, $n=7-8$ per group

$\left(p_{\mathrm{S}}<.001\right.$; Fig. 3a). Calculated from the cage preference data, the time-weighted average $T_{\mathrm{a}}$ the mice were exposed to when able to choose between 29 and $32{ }^{\circ} \mathrm{C}$ was significantly higher for female mice than male mice, without an effect of gonadal status (female sham $31.2 \pm$ $0.2^{\circ} \mathrm{C}$, female GDX $31.1 \pm 0.4{ }^{\circ} \mathrm{C}$, male sham $30.2 \pm 0.2{ }^{\circ} \mathrm{C}$, male GDX $30.4 \pm 0.3{ }^{\circ} \mathrm{C} ; p_{\mathrm{S}}<.001$; Fig. 3b). Thus, in general, the female mice preferred a higher $T_{\mathrm{a}}$ than male mice, a difference that was not affected by presence of the gonads.

Next, we determined whether $T_{\mathrm{a}}$ preference between the sexes was different in the active or inactive phase and found that the sex of mice influenced the thermal demand differently between the dark (active) phase $\left(p_{\mathrm{T}}\right.$ $<.001, p_{\mathrm{T} \times \mathrm{S} \times \mathrm{G}}=.002$; Fig. $3 \mathrm{c}$ ) and the light (inactive) phase $\left(p_{\mathrm{T}}<.001, p_{\mathrm{S}}<.001, \quad p_{\mathrm{T} \times \mathrm{S}}=.002, \quad p_{\mathrm{T} \times \mathrm{G}}=.013\right.$; Fig. 3e). When the experimental $T_{\mathrm{a}}$ was set at $26{ }^{\circ} \mathrm{C}$, sham-operated female, gonadectomized female, and gonadectomized male mice preferred to stay in the TMN cage in the dark phase, while sham-operated male mice had no preference to either cage in the dark phase. In the light phase, all groups preferred the TMN cage over the experimental $26{ }^{\circ} \mathrm{C}$ cage with a more prominent preference in male mice, without an effect of gonadal status. When the experimental $T_{\mathrm{a}}$ was set at $32{ }^{\circ} \mathrm{C}$, all groups equally resided in both the $32{ }^{\circ} \mathrm{C}$ and the TMN cages in the dark phase. In the light phase, shamoperated and gonadectomized female mice preferred the $32{ }^{\circ} \mathrm{C}$ cage over the TMN cage, whereas gonadectomized male mice preferred the TMN cage and sham-operated male mice showed no preference to either cage.

It is thus evident that GDX did not alter the sexdependent thermal preferences when analyzing the active and inactive phase independently, except only for the male mice in the dark phase at experimental $T_{\mathrm{a}}$ of $26{ }^{\circ} \mathrm{C}(p=.030)$. In addition, the time-weighted average $T_{\mathrm{a}}$, calculated from the location where the mice resided, was different between the active and inactive phases (Fig. 3d, f, respectively). The difference between male and female mice was the most obvious when they were able to choose between 29 and $32{ }^{\circ} \mathrm{C}$ in the inactive phase: female mice preferred higher $T_{\mathrm{a}}$ than male mice 


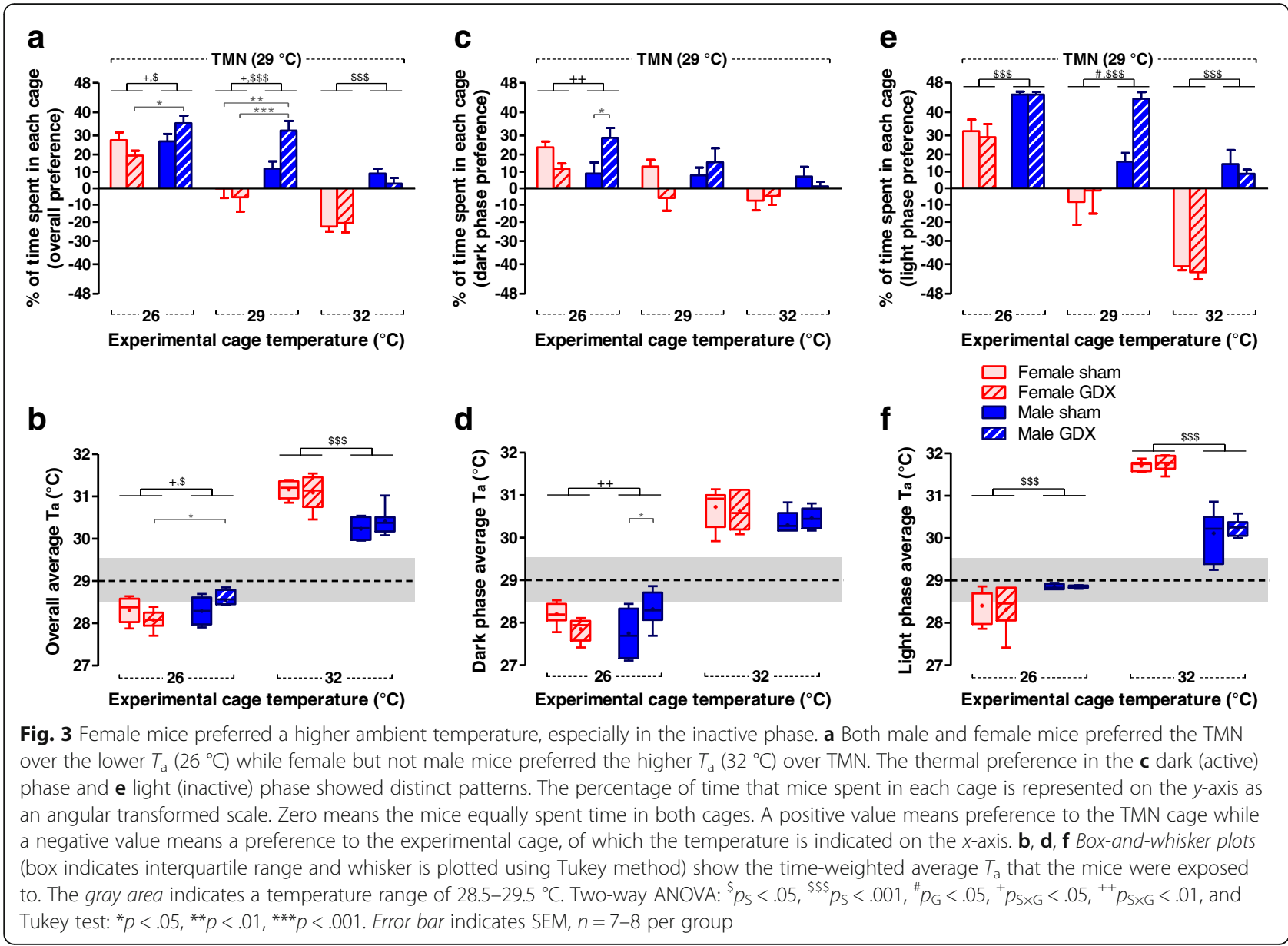

without an effect of gonadal status (female sham $31.7 \pm$ $0.1{ }^{\circ} \mathrm{C}$, female GDX $31.8 \pm 0.2{ }^{\circ} \mathrm{C}$, male sham $30.1 \pm 0.6{ }^{\circ} \mathrm{C}$, male GDX $30.2 \pm 0.2{ }^{\circ} \mathrm{C}$; $p_{\mathrm{S}}<.001$; Fig. 3f).

\section{The location of activities was affected mainly by ambient} temperature and partially by orchiectomy

The experimental $T_{\mathrm{a}}$ and sex influenced the transfer of nesting material by the mice $\left(p_{\mathrm{T}}<.001, p_{\mathrm{S}}<.001, p_{\mathrm{T} \times \mathrm{S}}\right.$ $=.013, p_{\mathrm{T} \times \mathrm{G}}=.021$; Fig. 4a). When the experimental $T_{\mathrm{a}}$ was at $26{ }^{\circ} \mathrm{C}$, all mice preferred to transfer the nesting material to the TMN cage. When the experimental $T_{\mathrm{a}}$ was at $32{ }^{\circ} \mathrm{C}$, female mice transferred the nesting material to this warmer cage while male mice did not transfer the nesting material at all. This trend of nest transfer to a warmer cage was similar to the temperature preference shown in Fig. 3a and was not affected by gonadal status. The "paperwork score," reflecting nest destructions, was only affected by the experimental $T_{\mathrm{a}}$ without an effect of sex or gonadal status $\left(p_{\mathrm{T}}<.001\right.$; Fig. $\left.4 \mathrm{~b}\right)$. The "nest score," which also takes the relative nest amount into account, was solely influenced by the experimental $T_{\mathrm{a}}\left(p_{\mathrm{T}}\right.$ $<.001$; Fig. 4c). Generally, the "nest score" negatively correlated with the experimental $T_{\mathrm{a}}$, but the correlations were only significant for sham-operated female mice $(r=-.47$, $p=.030)$ and gonadectomized male mice $(r=-.48, p$ $=.016)$.

The preference to consume food in the TMN or the experimental cage was not affected by experimental $T_{\mathrm{a}}$, sex, or gonadal status, but there was a significant interaction between sex and gonadal status $\left(p_{\mathrm{S} \times \mathrm{G}}=.042\right.$; Fig. $\left.4 \mathrm{~d}\right)$. All mice generally consumed the food equally from both cages except at the experimental temperature of $26{ }^{\circ} \mathrm{C}$ when sham-operated male mice preferred food from the $26{ }^{\circ} \mathrm{C}$ experimental cage while the gonadectomized male mice preferred food from the TMN cage. The position where mice preferred to defecate was dependent on the experimental $T_{\mathrm{a}}$ and the interactions between gonadal status and the other factors $\left(p_{\mathrm{T}}<.001, p_{\mathrm{T} \times \mathrm{G}}<.001\right.$, $p_{\mathrm{S} \times \mathrm{G}}=.002$; Fig. 4e). When the experimental $T_{\mathrm{a}}$ was set at $26{ }^{\circ} \mathrm{C}$, most mice predominantly defecated in the $26{ }^{\circ} \mathrm{C}$ cage, except gonadectomized male mice that had no preference to defecate in either cage. When the $T_{\mathrm{a}}$ was equal in both cages at $29{ }^{\circ} \mathrm{C}$, only sham-operated male mice preferred the experimental cage while the others defecated equally in both cages. 


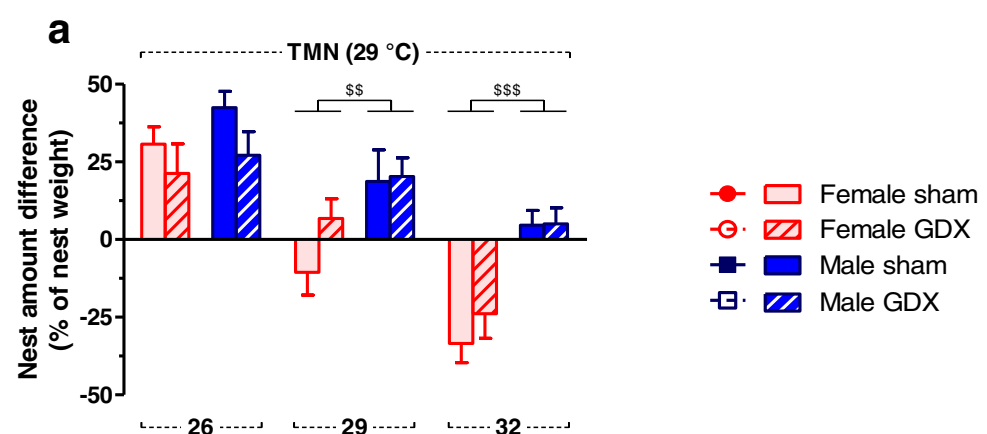

b

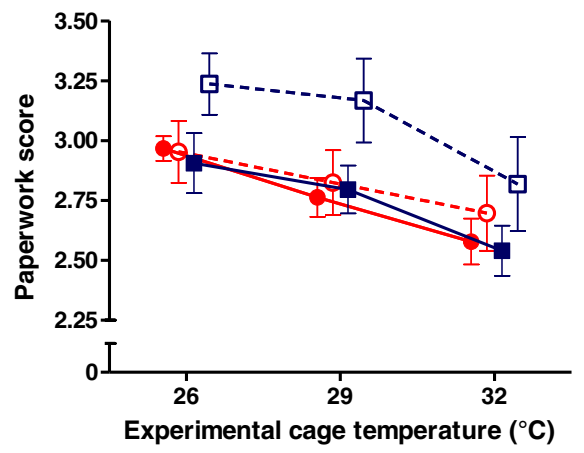

d

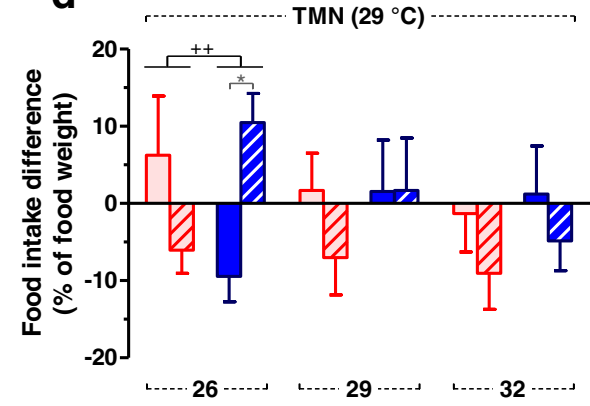

Experimental cage temperature $\left({ }^{\circ} \mathrm{C}\right)$
C
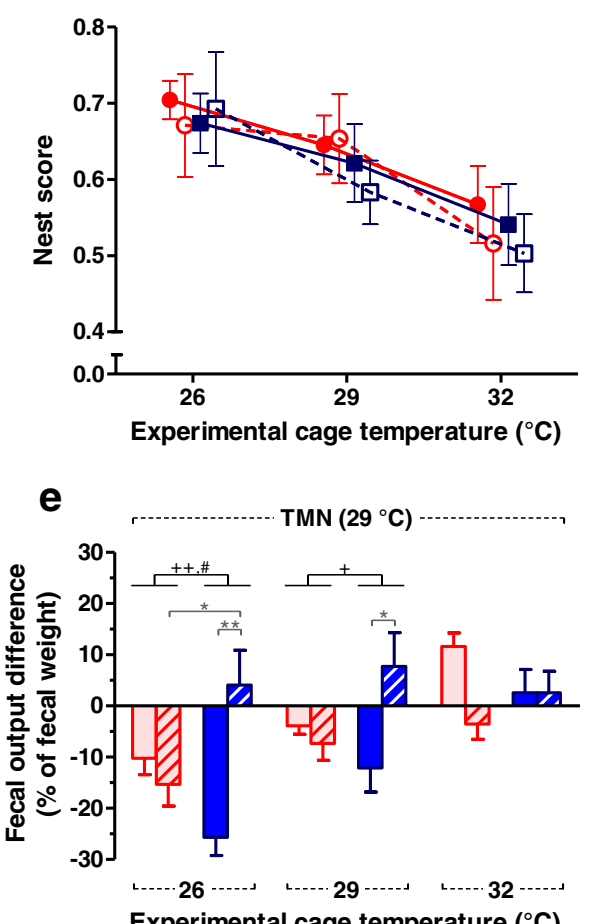

Fig. 4 The location of activities was affected mainly by ambient temperature and partially by orchiectomy. a At the experimental $T_{a}$ of $26^{\circ} \mathrm{C}$, all groups transferred the nest to the TMN cage, whereas at the experimental $T_{a}$ of $32{ }^{\circ} \mathrm{C}$, only female mice transferred the nest to the experimental cage. The difference of nest amount found in each cage is represented on the $y$-axis. Zero means the mice did not transfer the nesting material. A positive value means transfer of nesting material to the TMN cage while a negative value means transfer to the experimental cage, of which the $T_{\mathrm{a}}$ is indicated on the $x$-axis. Nest-relating activities revealed negative correlations of $T_{\mathrm{a}}$ to the $\mathbf{b}$ paperwork score and $\mathbf{c}$ nest score without an effect of sex or gonadal status. The experimental $T_{a}$, sex or gonadal status did not affect $\mathbf{d}$ the preferred cage for food consumption, but orchiectomy and the experimental $T_{\mathrm{a}}$ altered $\mathrm{e}$ the preferred cage for defecation. Two-way ANOVA: ${ }^{\$ \$} p_{\mathrm{S}}<.01,{ }^{\$ \$ \$} p_{\mathrm{S}}<.001,{ }^{\#} p_{\mathrm{G}}<.05,{ }^{+} p_{\mathrm{S} \times \mathrm{G}}<.05,{ }^{++} p_{\mathrm{S} \times \mathrm{G}}<.01$, and Tukey test: ${ }^{*} p<.05,{ }^{* *} p<.01$. Error bar indicates $\mathrm{SEM}, n=7-8$ per group

When the experimental $T_{\mathrm{a}}$ was at $32{ }^{\circ} \mathrm{C}$, shamoperated female mice defecated more in the TMN cage, while mice of the other groups showed no preference. Interestingly, when correlating the nestbuilding pattern (the cage with a higher nest score) with the defecating pattern, it was evident that while all other mice defecated in the cage without the nest, gonadectomized male mice defecated more in the cage where they had built their nest.

\section{Discussion}

The data presented in this paper demonstrate that female mice prefer a warmer environment than male mice, in agreement with previous studies $[10,21]$. This article is the first to show that this sex difference in thermal preference in adult mice is not altered by GDX, suggesting that gonadal hormones are not the main driver of this sex difference in adult mice. 
The preference to a higher $T_{\mathrm{a}}$ of female mice could be explained by many other mechanisms involving a complex circuit that controls whole body thermal and energy homeostasis. The differences in body compositions may affect thermal preferences. We found that female C57BL/6J mice had a higher BSA to body mass ratio than male mice of the same age. Therefore, the female mice likely had a higher heat dissipation rate from the skin to the environment and consequently a higher energy demand than male mice which may have resulted in the preference to reside at a higher $T_{\mathrm{a}}$. Moreover, this may have resulted in a higher relative daily food intake to match the higher passive heat loss. The higher food consumption of female mice was also noted in a previous study [22].

The body composition of C57BL/6J mice is sexually dimorphic: male mice have a higher lean body mass [23] with relatively more skeletal muscle mass [24] than female mice. Because heat is a byproduct of muscular activities, the higher muscle mass in male mice could explain why male mice have generally less thermal demand compared to female mice. Paul et al. [24] found that GDX abolished the sex-specific pattern of muscle mass leading to a reduction in muscle mass in castrated male mice to a comparable amount as found in ovariectomized and sham-operated female mice. This effect of castration could also explain the higher thermal demand of castrated male mice compared to sham-operated male mice in our study, while ovariectomy did not alter the thermal preference of female mice in the active phase at $T_{\mathrm{a}}$ of $26^{\circ} \mathrm{C}$.

Control of $T_{\mathrm{c}}$ is regulated by the brain. The preoptic area of the anterior hypothalamus (POAH) is the primary site that integrates afferent signals from peripheral thermoreceptors to control the physiological responses through projections to other hypothalamic areas that modulate non-shivering thermogenesis of BAT to match the overall thermal demand [25-27]. The female gonadal steroids estradiol and progesterone differently modulate the thermoregulatory set point during the estrous cycle of mammals. A decline of $T_{\mathrm{c}}$ in the pre-ovulatory phase is related to estrogen secretion in that phase while progesterone secretion at the luteal phase increases $T_{\mathrm{c}}$ $[11,28]$. Furthermore, there is evidence that estradiol and testosterone differentially affect steroid-sensitive neurons in the POAH of rats [29] and the central set point of temperature in different groups of hypothalamic neurons $[12,26]$. We found that when the mice were allowed to choose between 32 and $29{ }^{\circ} \mathrm{C}$, the overall average preferred $T_{\mathrm{a}}$ was higher for female mice than for male mice in the inactive phase, suggesting a sexdependent regulation of the temperature set point in the mouse brain. However, since our study revealed that the removal of gonadal hormones by GDX did not affect the thermal preference of both male and female mice, we cannot conclude that the sexdependent regulation of the temperature set point in the POAH depends on the different gonadal hormones. Nevertheless, effects of gonadal hormones outside the brain might be involved. For instance, estradiol, progesterone, or testosterone differentially stimulated or inhibited the peripheral thermoreceptors [30], and estradiol and progesterone induce while testosterone reduces the thermogenesis of BAT [31, 32].

It is highly unlikely that the lack of an effect of GDX on thermal preference found in our studies is due to the sustained presence of sex hormones after GDX. Steroid hormones, including sex hormones, generally have half-lives of 4-170 min [33]. In C57BL/ 6 mice, the half-lives of $17 \beta$-estradiol and testosterone are less than $1 \mathrm{~h}[34,35]$. Moreover, locomotor activities and circadian rhythms have been shown to be altered as soon as 1 week after GDX [36].

Since we did not find an effect of post-pubertal GDX on thermal preference in adult mice, it is plausible that the mechanisms underlying the sex difference in thermal preference were generated prior to puberty. Sex hormones have permanent organizational effects on brain development during two sensitive periods [37]. Perinatally, testosterone secreted from the testes masculinizes the neural circuit in male mice while androgen absence in female rodents feminizes the nervous system. During puberty, elevations of gonadal hormones due to maturation of the hypothalamic-pituitary-gonadal axis strengthen the sex-dependent behaviors. In addition, it is reported that the POAH is a sexually dimorphic region in which morphological changes develop during puberty and that exposure to estrogenic compounds at puberty disturbs the development of neuronal circuits [38, 39].

\section{Conclusions}

In summary, we found that adult female mice preferred a warmer environment than male mice of the same age, a difference that was especially apparent in the inactive phase. However, this sex difference did not depend on the presence of gonads. The sex difference in thermal preference in adult mice might be influenced by other sex-specific pathways rather than the gonadal factors or the central set point that controls the thermal balance has already been established at pre-pubertal stages.

\section{Additional file}

Additional file 1: Figure S1. Paperwork score shows the nesting material of each score. Table $\mathbf{S 1}$. Baseline characteristics indicate the animal data from the adaptation weeks. (PDF $147 \mathrm{~kb}$ ) 


\section{Abbreviations}

BAT: Brown adipose tissue; BSA: Body surface area; BW: Body weight; GDX: Gonadectomy; POAH: Preoptic area of the anterior hypothalamus: $T_{\mathrm{a}}$ : Ambient temperature; $T_{c}$ : Core body temperature; TMN: Thermoneutral; TNZ: Thermoneutral zone; TPT: Temperature preference test

\section{Acknowledgements}

The authors would like to thank E.M. Baarsma, R. Duister, E. Hoogendoorn and E.L. Looman for the development of the TPT setup and experiments, and thank K. Meesilpavikkai, M.A. Vonk Noordegraaf, and K. Wejaphikul for the assessment of the paperwork score.

\section{Funding}

This research was supported mainly by the Department of Internal Medicine, Erasmus MC, Rotterdam, the Netherlands, and partly by Faculty of Medicine, Chulalongkorn University, Bangkok, Thailand.

\section{Availability of data and materials}

The datasets generated and/or analyzed during the current study are available from the corresponding author on reasonable request.

\section{Authors' contributions}

AG and APNT conceived the study. KK, AG, and JS designed and performed the experiments and collected the data. $K K, A G$, and JAV analyzed the data. KK wrote the paper. All authors provided valuable feedback on the manuscript and approved the final manuscript.

\section{Ethics approva}

All experimental procedures were performed with the approval of the Animal Ethics Committee at Erasmus MC, Rotterdam, the Netherlands.

\section{Consent for publication}

Not applicable

\section{Competing interests}

The authors declare that they have no competing interests.

\section{Publisher's Note}

Springer Nature remains neutral with regard to jurisdictional claims in published maps and institutional affiliations.

\section{Author details}

'Department of Internal Medicine, Erasmus MC, University Medical Center Rotterdam, PO Box 2040, 3000 CA Rotterdam, The Netherlands. ${ }^{2}$ Department of Physiology, Faculty of Medicine, Chulalongkorn University, 1873, Rama IV Road, Pathumwan, Bangkok 10330, Thailand.

Received: 19 May 2017 Accepted: 28 June 2017

Published online: 11 July 2017

\section{References}

1. IUPS Thermal Commission. Glossary of terms for thermal physiology. Jpn J Physiol. 2001;51:245-80.

2. Swoap SJ, Li C, Wess J, Parsons AD, Williams TD, Overton JM. Vagal tone dominates autonomic control of mouse heart rate at thermoneutrality. Am J Physiol Heart Circ Physiol. 2008;294:H1581-8.

3. Yamauchi C, Fujita S, Obara T, Ueda T. Effects of room temperature on reproduction, body and organ weights, food and water intakes, and hematology in mice. Exp Anim. 1983;32:1-11.

4. Gordon CJ. Temperature regulation in laboratory rodents. Cambridge: Cambridge University Press; 1993.

5. Havenaar R, Meijer JC, Morton DB, Ritskes-Hoitinga J, Zwart P. Biology and husbandry of laboratory animals. In: Van Zutphen LFM, Baumans V, Beynen AC, editors. Principles of laboratory animal science. Secondth ed. Amsterdam: Elsevier; 2001. p. 19-76.

6. Gordon CJ, Becker P, Ali JS. Behavioral thermoregulatory responses of single- and group-housed mice. Physiol Behav. 1998:65:255-62.

7. Maloney SK, Fuller A, Mitchell D, Gordon C, Overton JM. Translating anima model research: does it matter that our rodents are cold? Physiology (Bethesda). 2014;29:413-20
8. Cannon B, Nedergaard J. Nonshivering thermogenesis and its adequate measurement in metabolic studies. J Exp Biol. 2011;214:242-53.

9. Schmidt-Nielsen K. Warm-blooded vertebrates: what do metabolic regression equations mean? In: Scaling: Why is Animal Size so Important? Cambridge: Cambridge University Press; 1984. p. 75-89.

10. Gaskill BN, Rohr SA, Pajor EA, Lucas JR, Garner JP. Some like it hot: mouse temperature preferences in laboratory housing. Appl Anim Behav Sci. 2009; 116:279-85.

11. Sanchez-Alavez M, Alboni S, Conti B. Sex- and age-specific differences in core body temperature of C57BI/6 mice. Age (Dordr). 2011;33:89-99.

12. Charkoudian N, Stachenfeld N. Sex hormone effects on autonomic mechanisms of thermoregulation in humans. Auton Neurosci. 2016;196:75-80.

13. Stouffer RL, Hennebold JD. Structure, function, and regulation of the corpus luteum. In: Plant TM, Zeleznik AJ, editors. Knobil and Neill's Physiology of Reproduction. Fourth Edition. San Diego: Academic; 2015. p. 1023-76.

14. Sinchak K, Wagner EJ. Estradiol signaling in the regulation of reproduction and energy balance. Front Neuroendocrinol. 2012;33:342-63.

15. Martínez de Morentin Pablo B, González-García I, Martins L, Lage R, Fernández-Mallo D, Martínez-Sánchez N, et al. Estradiol regulates brown adipose tissue thermogenesis via hypothalamic AMPK. Cell Metab. 2014;20:41-53.

16. Rodriguez AM, Monjo M, Roca P, Palou A. Opposite actions of testosterone and progesterone on UCP1 mRNA expression in cultured brown adipocytes. Cell Mol Life Sci. 2002:59:1714-23.

17. Rodriguez-Cuenca S, Monjo M, Gianotti M, Proenza AM, Roca P. Expression of mitochondrial biogenesis-signaling factors in brown adipocytes is influenced specifically by 17 beta-estradiol, testosterone, and progesterone Am J Physiol Endocrinol Metab. 2007:292:E340-6.

18. Gaskill BN, Gordon CJ, Pajor EA, Lucas JR, Davis JK, Garner JP. Heat or insulation: behavioral titration of mouse preference for warmth or access to a nest. PLoS One. 2012;7:e32799.

19. Kalueff AV, Keisala T, Minasyan A, Kuuslahti M, Miettinen S, Tuohimaa P. Behavioural anomalies in mice evoked by "Tokyo" disruption of the vitamin D receptor gene. Neurosci Res. 2006:54:254-60.

20. Cheung MC, Spalding PB, Gutierrez JC, Balkan W, Namias N, Koniaris LG, Zimmers TA. Body surface area prediction in normal, hypermuscular, and obese mice. J Surg Res. 2009;153:326-31.

21. Gaskill BN, Rohr SA, Pajor EA, Lucas JR, Garner JP. Working with what you've got: changes in thermal preference and behavior in mice with or without nesting material. J Therm Biol. 2011;36:193-9.

22. Comprehensive metabolic survey of 16 inbred strains of mice. MPD:9233. Mouse Phenome Database website. Seburn KL. 2001. http://phenome.jax. org. Accessed 30 Nov 2016

23. Densitometric survey of 11 strains of mice. MPD:Jaxpheno1. Mouse Phenome Database website. The Jackson Laboratory. 2006. http://phenome. jax.org. Accessed 30 Nov 2016

24. Paul R, McMahon C, Elston M, Conaglen J: Regulation of murine skeletal muscle mass by testosterone and 17 $\beta$-oestradiol. In 17th European Congress of Endocrinology: 16-20 May 2015: Dublin, Ireland. Edited by Arlt W, Visser J, Beuschlein F. Endocrine Abstracts; 2015: GP.05.1

25. Boulant JA. Neuronal basis of Hammel's model for set-point thermoregulation. J Appl Physiol. 2006;100:1347-54.

26. Boulant JA. Hypothalamic neurons regulating body temperature. In: Comprehensive Physiology. Hoboken: Wiley; 2010. p. 105-26.

27. Saper CB, Lowell BB. The hypothalamus. Curr Biol. 2014;24:R1111-6.

28. Kaciuba-Uscilko H, Grucza R. Gender differences in thermoregulation. Curr Opin Clin Nutr Metab Care. 2001:4:533-6.

29. Silva NL, Boulant JA. Effects of testosterone, estradiol, and temperature on neurons in preoptic tissue slices. Am J Physiol. 1986;250:R625-32.

30. Kondrats'kyi AP, Kondrats'ka KO, Skryma R, Prevars'ka N, Shuba la M. Gender differences in cold sensitivity: role of hormonal regulation of TRPM8 channel [abstract]. Fiziol Zh. 2009:55:91-9.

31. Quarta C, Mazza R, Pasquali R, Pagotto U. Role of sex hormones in modulation of brown adipose tissue activity. J Mol Endocrinol. 2012:49:R1-7.

32. Law J, Bloor I, Budge H, Symonds ME. The influence of sex steroids on adipose tissue growth and function. Horm Mol Biol Clin Invest. 2014;19:13-24.

33. Molina PE. Chapter 1. General principles of endocrine physiology. In: Endocrine Physiology, 4e. New York: The McGraw-Hill Companies; 2013.

34. Laurent MR, Hammond GL, Blokland M, Jardi F, Antonio L, Dubois V, et al. Sex hormone-binding globulin regulation of androgen bioactivity in vivo: validation of the free hormone hypothesis. Sci Rep. 2016;6:35539. 
35. Deshpande D, Kethireddy S, Gattacceca F, Amiji M. Comparative pharmacokinetics and tissue distribution analysis of systemically administered $17-\beta$-estradiol and its metabolites in vivo delivered using a cationic nanoemulsion or a peptide-modified nanoemulsion system for targeting atherosclerosis. J Control Release. 2014;180:117-24.

36. Iwahana E, Karatsoreos I, Shibata S, Silver R. Gonadectomy reveals sex differences in circadian rhythms and suprachiasmatic nucleus androgen receptors in mice. Eur J Neurosci. 2008;27:432-43.

37. Sisk CL, Zehr JL. Pubertal hormones organize the adolescent brain and behavior. Front Neuroendocrinol. 2005;26:163-74.

38. Ceccarelli I, Della Seta D, Fiorenzani P, Farabollini F, Aloisi AM. Estrogenic chemicals at puberty change ERa in the hypothalamus of male and female rats. Neurotoxicol Teratol. 2007;29:108-15.

39. Tabarean I, Morrison B, Marcondes MC, Bartfai T, Conti B. Hypothalamic and dietary control of temperature-mediated longevity. Ageing Res Rev. 2010;9:41.

Submit your next manuscript to BioMed Central and we will help you at every step:

- We accept pre-submission inquiries

- Our selector tool helps you to find the most relevant journal

- We provide round the clock customer support

- Convenient online submission

- Thorough peer review

- Inclusion in PubMed and all major indexing services

- Maximum visibility for your research

Submit your manuscript at www.biomedcentral.com/submit
Biomed Central 